\title{
SOUTH AFRICAN STUDENTS PERCEPTIONS OF THE USEFULNESS OF A MANAGEMENT ACCOUNTING SIMULATION
}

\author{
Riaan J Rudman* \\ Stellenbosch University \\ rjrudman@sun.ac.za
}

Received: November 2012

\author{
Wandi Kruger-van Renen" \\ Stellenbosch University \\ wandivanrenen@sun.ac.za
}

Accepted: November 2013

\begin{abstract}
Professional bodies such as the International Federation of Accountants and related bodies such as the South African Institute of Chartered Accountants require Information Technology (IT) to be integrated with the professional subjects, which includes Management Accounting. This has been a recent development in the training of professional accountants. Historically, universities have mainly focused on numerical problem-solving, but there has been a shift in focus from numerical problemsolving only to integrating numerical problem-solving with strategic and business matters.

The Department of Accounting at Stellenbosch University developed a management accounting simulation in the form of a business plan project covering the entire process of launching a new business idea. Students select a new business concept, research the viability thereof and prepare various sets of financial information and a business plan. The learning objective of the simulation is to integrate management accounting with IT, and expose students to a real-life business experience.

A questionnaire was developed to evaluate students' perceptions of the benefits and disadvantages of a simulation, including a business plan project as a teaching tool. Responses to the appropriateness of a simulation as a teaching tool were favourable. Respondents felt that it helped them to understand both management accounting as well as IT functionalities better.
\end{abstract}

Keywords

Information systems; Information technology; Management accounting education; Management accounting simulation; Students' perceptions

*Mr RJ Rudman is a lecturer in the Department of Accounting, University of Stellenbosch, South Africa.

\#Mrs W Kruger-van Renen is a lecturer at the Department of Accounting, University of Stellenbosch, South Africa. 


\section{INTRODUCTION}

Many have argued in favour of transforming the approach in which accounting programmes are presented to undergraduate students (henceforth referred to as students) (Accounting Education Change Commission, 1990; Stewart \& Dougherty, 1993; Massey, Poli \& Proctor, 2002; Ahadiat, 2008). These calls for transformation have included proposals that Information Technology (IT) should be integrated into the accounting curricula for all subjects (Johnson, Baird, Caster, Dilla, Earley \& Louwers, 2003), while also requiring that students participate more actively in the learning process (Adler \& Milne, 1997; Hassall, Lewis \& Broadbent, 1998). Siegel, Omer and Agrawal (1997) criticised tertiary education in the United States of America on account of the unresponsive manner in which students are lectured and that written examinations are not deemed appropriate for use to evaluate knowledge and understanding. Botha (2001) argued that it appeared that the student's aim in the learning process in accounting programmes mainly concerned the passing of examinations, particularly because written examinations were used to assess students and evaluate professional competence. Steenkamp and Rudman (2007) argued that the manner of assessments might result in students acquiring a strong theoretical base, but not necessarily a good skills base and competencies required when entering an accounting-related work environment. The work environment expects students to be able to solve new, unstructured problems and consider a variety of aspects. Merely being able to memorise the answers to existing problems is inadequate preparation for a student to be able to solve new problems. The need has therefore arisen for a new kind of learning experience (Springer \& Borthick, 2004). Siegel et al. (1997) argued that students, in general, have not been exposed to the business world and are not familiar with the usual activities that form the basis of being an accountant. This makes it difficult for students to understand the field of management accounting. Albrecht and Sack (2000:43) have also argued that accounting programmes do not prepare students sufficiently for the 'ambiguous business world they will encounter upon graduation; due to the lack of work experience'. Firms want students to be able to apply theoretical knowledge in 'real-world' scenarios during their studies (Horsfield, 1995:298). The work environment requires employees to be proficient in the use of IT (Borthick \& Curtis, 2004). This places a responsibility on educators to integrate IT skills with the professional subjects such as auditing, financial accounting, management accounting and finance and taxation (Wessels, 2005). Because of various constraints (such as large class sizes, a full academic programme, and financial considerations) it is not possible to give all students exposure to the business world. Other teaching methods therefore need to be investigated. Methods such as simulations give students the opportunity to 'learn by doing' (Wynder, 2004:231). Simulations also give students the opportunity to learn to solve problems by constructing their own representations of the situation and developing and presenting suitable solutions for a specific situation (Springer \& Borthick, 2004).

Against this background, the South African Institute of Chartered Accountants (SAICA) has developed the Competency Framework to describe the knowledge, skills and attributes that a Chartered Accountant (CA(SA)) should demonstrate at entry point to the profession (SAICA, 2010). SAICA is not the only professional organisation that investigated a new training framework. The Chartered Institute of Management Accountants (CIMA) (2010) and the South African Institute of Professional Accountants (SAIPA) have also made significant changes to their curriculum. Greater focus in the curriculum is placed on skills development in the areas of (1) pervasive skills (divided into business ethics and professionalism, management and leadership (professional skills) and personal attributes), (2) management decision-making, as 
well as (3) subject-specific knowledge. Since the Department of Accounting at Stellenbosch University is educating future professional accountants, the department is obliged to present a course that ensures that the skills set out by these professional bodies are developed in students. In an effort to inculcate some of the above-mentioned knowledge, skills and attributes in its graduates, the Department of Accounting has developed a management accounting simulation in which students are required to prepare a business plan, using their management accounting knowledge and IT skills. This research reports on the perceptions of students on the usefulness of this management accounting simulation incorporating a business plan project to develop various skills and knowledge.

The research commences with the research objective, followed by a review of existing international research literature. The research design and method is discussed in section 4 , and this is followed by a description of the management accounting simulation incorporating the business plan project. The results of the questionnaire are presented in section 6, and are followed by the conclusion.

\section{RESEARCH OBJECTIVE AND CONTRIBUTION}

The purpose of incorporating a business plan project in the management accounting simulation was to integrate management accounting with IT and allow students to prepare a strategic business plan that sets out the best strategy for a particular organisation. This simulates a reallife business in the classroom.

The primary objective of this research was to investigate students' perceptions of the usefulness of the management accounting simulation incorporating a business plan project (henceforth referred to as a management accounting simulation) as an instrument to develop knowledge and skills as part of their information systems studies. The research therefore undertook to answer the following questions:

- Which competencies were developed by the management accounting simulation?

- What were the most important perceived benefits derived from the management accounting simulation?

- What were the main constraints to the management accounting simulation?

This research makes a contribution to the field of knowledge concerning the use of simulations and business plan projects in the area of business-related subjects and may be valuable in developing similar teaching aids in other areas, such as finance, accounting, et cetera, which historically has not been taught by means of experiential learning methods. It adds to the ongoing discussion about changes needed in accounting education in a South African context. It also supports the argument that IT should not be taught as a separate subject, but should rather form part of another subject, such as one of the professional subjects. This research is also relevant to educators in general, because the principles and findings are applicable to a simulation in any environment, as well as to the use of other experiential teaching aids such as case studies that take the same form and structure. 


\section{LITERATURE REVIEW}

Many studies have indicated that the most important skills and competencies that a prospective accountant should have include: general business knowledge; accounting knowledge; computer skills (Palmer, Ziegenfuss \& Pinsker, 2004); problem-solving skills; and interpersonal skills. The American Accounting Association (1989) 'White paper' concluded that students should be taught conceptual thinking, rather than simply memorising theory. The SAICA (2010) Competency Framework attempts to address this by requiring students to conceptualise the business environment within each academic subject. It may be argued that accounting students are required 'to apply the theoretical knowledge they have been taught to the practical business environments that they must visualise, and then conceptualise a course of action' (Rudman \& Terblanche, 2011:63). This leaves accounting educators with the challenge of teaching students the ability to apply the theory they are taught in class to practice after graduating (Rudman \& Terblanche, 2011). The use of simulations and projects may assist educators in instilling many of these skills and competencies.

In professional accounting programmes, students do not have sufficient exposure to the business environment, which results in a need for supplementary aids to complement the theory lectures, particularly in a South African context (Steenkamp \& Rudman, 2007; Rudman \& Terblanche, 2011). A review of international studies on management accounting simulations, as well as students' perceptions of these simulations and case studies, is presented in this section. Literature on management accounting simulations is limited; however, studies that investigate other teaching tools (i.e. experiential learning tools) to complement traditional theory lectures are available. Experiential learning can be defined as learning with clear objectives that facilitate exposure to the environment (Gentry, 1990). Various experiential learning techniques are available. Wolmarans (2005) argues that a business simulation meets the criteria for a method of experiential learning; a management accounting simulation, similarly, could also meet the criteria for a method of experiential learning, since students are actively involved in the learning process and are required to apply theoretical knowledge. TABLE l presents a summary of key findings from prior research studies that used a wide range of teaching tools other than traditional theory lectures. The key findings of the majority of the papers presented in TABLE 1 can be summarised as:

- students struggle to find the link between theory and practice;

- theoretical classes do not prepare students for the real world;

- students struggle to conceptualise the theory they are taught;

- students struggle to visualise the learning process; and

- students struggle to see the big picture, thus they are unable to identify how the individual concepts fit together.

Since many of the studies presented similar findings, only the key findings unique to each study are presented. 


\section{TABLE 1: Summary of key research findings from prior research}

\begin{tabular}{|c|c|c|}
\hline $\begin{array}{l}\text { Research } \\
\text { performed by }\end{array}$ & $\begin{array}{l}\text { Experiential } \\
\text { learning method } \\
\text { used (if applicable) }\end{array}$ & Key findings \\
\hline $\begin{array}{l}\text { Albrecht \& Sack } \\
(2000)\end{array}$ & & $\begin{array}{l}\text { - Accounting courses are not adequate in preparing } \\
\text { students for the business world after graduation. }\end{array}$ \\
\hline Dennis (2003) & Case study & $\begin{array}{l}\text { - Marks for the subject of auditing increase due to } \\
\text { exposure to the case study (students had to } \\
\text { distinguish between theoretical and practical } \\
\text { auditing). }\end{array}$ \\
\hline $\begin{array}{l}\text { De Wet \& Van } \\
\text { Niekerk }(2001)\end{array}$ & $\begin{array}{l}\text { Innovative changes } \\
\text { in the classroom }\end{array}$ & $\begin{array}{l}\text { - Respondents suggested that the course should be more } \\
\text { practice-oriented by introducing visits to business as } \\
\text { well as practical case studies. } \\
\text { - Greater prominence is given to conceptualising when } \\
\text { new techniques are used. }\end{array}$ \\
\hline $\begin{array}{l}\text { Flores, Ritchie \& } \\
\text { Wolfe (2008) }\end{array}$ & $\begin{array}{l}\text { Strategic } \\
\text { management } \\
\text { simulation for } \\
\text { distance education }\end{array}$ & $\begin{array}{l}\text { - Distance education may have the advantage of } \\
\text { fostering learning and relieving the instructor of } \\
\text { simulation-processing chores. } \\
\text { - However, students under traditional instruction } \\
\text { receive a more productive experience, as they have the } \\
\text { opportunity to interact with the instructor. }\end{array}$ \\
\hline $\begin{array}{l}\text { Lightbody } \\
\text { (1997) }\end{array}$ & $\begin{array}{l}\text { Activity-based } \\
\text { simulation - cost } \\
\text { and management } \\
\text { accounting module }\end{array}$ & $\begin{array}{l}\text { - Simulations as teaching tools offer an effective way of } \\
\text { integrating management accounting theory and } \\
\text { practice. }\end{array}$ \\
\hline $\begin{array}{l}\text { Massey, Poli \& } \\
\text { Proctor (2002) }\end{array}$ & $\begin{array}{l}\text { Business simulation } \\
\text { - introductory } \\
\text { auditing course }\end{array}$ & $\begin{array}{l}\text { - Simulations enhance understanding of auditing } \\
\text { knowledge after completion of the simulation. }\end{array}$ \\
\hline May (1992) & Video simulation & $\begin{array}{l}\text { - Auditing is a complex subject to teach. } \\
\text { - It is made more difficult because terminology used in } \\
\text { auditing is unknown to students. } \\
\text { - Students who had prior business exposure could } \\
\text { visualise the 'big picture' behind the subject of } \\
\text { auditing, whilst students without business exposure } \\
\text { were not able to do so. }\end{array}$ \\
\hline $\begin{array}{l}\text { Rudman \& } \\
\text { Terblanche } \\
\text { (2011) }\end{array}$ & Role-playing & $\begin{array}{l}\text { - An incremental value can be added to audit education } \\
\text { by using role-playing as a teaching tool as role- } \\
\text { playing assists students in thinking conceptually about } \\
\text { theoretical concepts underlying auditing. }\end{array}$ \\
\hline $\begin{array}{l}\text { Sadler \& } \\
\text { Erasmus (2005) }\end{array}$ & & $\begin{array}{l}\text { More than } 50 \% \text { of the respondents indicated that they } \\
\text { had too little exposure to business and that this lack } \\
\text { of exposure had an impact on their success or failure. }\end{array}$ \\
\hline Sawyer, & Taxation case study & - Competencies such as decision-making and problem- \\
\hline
\end{tabular}




\begin{tabular}{|c|c|c|}
\hline $\begin{array}{l}\text { Research } \\
\text { performed by }\end{array}$ & $\begin{array}{l}\text { Experiential } \\
\text { learning method } \\
\text { used (if applicable) }\end{array}$ & Key findings \\
\hline $\begin{array}{l}\text { Tomlinson \& } \\
\text { Maples }(2000)\end{array}$ & & $\begin{array}{l}\text { solving can be developed in students only if an } \\
\text { interactive environment between the student and real } \\
\text { life is created within the classroom. }\end{array}$ \\
\hline $\begin{array}{l}\text { Stainbank } \\
(2003)\end{array}$ & $\begin{array}{l}\text { Annual report } \\
\text { project }\end{array}$ & $\begin{array}{l}\text { - Respondents valued the exposure to a practical } \\
\text { approach and the unknown business environment. }\end{array}$ \\
\hline $\begin{array}{l}\text { Stainbank } \\
(2005)\end{array}$ & $\begin{array}{l}\text { Annual report } \\
\text { project }\end{array}$ & $\begin{array}{l}\text { - Respondents indicated that an important benefit was } \\
\text { created because the project enabled them to visualise } \\
\text { different theoretical concepts after exposure to a } \\
\text { practical business environment. }\end{array}$ \\
\hline $\begin{array}{l}\text { Steenkamp \& } \\
\text { Rudman (2007) }\end{array}$ & $\begin{array}{l}\text { Simulation - } \\
\text { combining infor- } \\
\text { mation technology } \\
\text { and auditing }\end{array}$ & $\begin{array}{l}\text { - Respondents were positive that practical simulations } \\
\text { should be included within all the core subjects of the } \\
\text { professional accounting programme. } \\
\text { - Respondents found the simulation to be time- } \\
\text { consuming. }\end{array}$ \\
\hline $\begin{array}{l}\text { Visser, McChlery } \\
\text { \& Vreken (2006) }\end{array}$ & $\begin{array}{l}\text { Teaching styles of } \\
\text { lecturers compared } \\
\text { to learning styles of } \\
\text { students }\end{array}$ & $\begin{array}{l}\text { - Accounting students tended to combine } \\
\text { conceptualisation and experimentation for a maximum } \\
\text { learning experience when presented with alternatives. }\end{array}$ \\
\hline $\begin{array}{l}\text { Wessels \& } \\
\text { Steenkamp } \\
(2007)\end{array}$ & & $\begin{array}{l}\text { - Although students were aware of the theoretical } \\
\text { aspects, they did not apply this knowledge in practice. } \\
\text { - This non-application is attributed to students not } \\
\text { being exposed to real-life business situations. }\end{array}$ \\
\hline $\begin{array}{l}\text { Wessels \& } \\
\text { Steenkamp } \\
(2009)\end{array}$ & & $\begin{array}{l}\text { - Business awareness, professional and technical } \\
\text { abilities are skill requirements of professional } \\
\text { accounting bodies. These competencies could be } \\
\text { ingrained during the academic programme if there } \\
\text { would be sufficient exposure to real-life practical } \\
\text { business environments. }\end{array}$ \\
\hline $\begin{array}{l}\text { Wolmarans } \\
(2005)\end{array}$ & $\begin{array}{l}\text { Financial and } \\
\text { project manage- } \\
\text { ment business } \\
\text { simulation }\end{array}$ & $\begin{array}{l}\text { - Business simulations play an important role, since } \\
\text { students are able to link theory to practice. } \\
\text { - Students obtained a better 'big picture' and their } \\
\text { financial knowledge improved. }\end{array}$ \\
\hline Wynder (2004) & $\begin{array}{l}\text { Computerised } \\
\text { business simulation } \\
\text { second-year } \\
\text { management } \\
\text { accounting course }\end{array}$ & $\begin{array}{l}\text { - A computerised business simulation provided a vehicle } \\
\text { for students to acquire and apply domain relevant } \\
\text { knowledge to generate creative solutions to unique } \\
\text { business problems. }\end{array}$ \\
\hline
\end{tabular}

Source: Rudman and Terblanche (adapted), 2011 
Many students perceive management accounting topics as either difficult, boring or both (Lightbody, 1997). For this reason, Lightbody (1997) designed an activity-based simulation in cost and management accounting. He identified a number of educational benefits:

- the exercise improved the comprehension of management accounting subjects;

- student participation in management accounting topics in class increased; and

- students' enthusiasm for management accounting topics seemed to have been increased by the simulation exercise.

He concluded that using simulations as a teaching tool may offer an effective way of integrating management accounting theory and practice.

Wynder (2004) developed a computerised business simulation in a second-year management accounting course, because he argued that students learn more from actively engaging the subject and that experience is not gained by simply observing something, but that an active engagement with the specific environment is necessary. The usefulness of simulations is further stressed as potential employers are increasingly requiring students to have the ability to deal with unstructured tasks (Wynder, 2004).

An analysis of students' perceptions of the usefulness of the case study method in an advanced management accounting module was conducted by Ballantine and Larres (2004). They evaluated whether a student who has already had experience of accounting-related problems through part-time employment had a different perception of the benefits of the case study method than students without prior experience. The result showed that students with relevant work experience did not perceive the case study method as more beneficial than those students without relevant work experience did.

Ahadiat (2008) conducted a survey among accounting practitioners to determine the topics they felt were imperative and relevant for management accountants in their companies. The research called for major changes in the accounting curriculum. Ahadiat (2008) recommended that certain factors (or topics) should be included in the management accountant's curriculum. Students should be:

- trained in ethics;

- well-prepared to use IT, particularly spreadsheet applications (this is one of the outcomes of the simulation and project presented at Stellenbosch University) and

- taught to think strategically and learn organisational skills (this is another of the outcomes of the simulation and project presented at Stellenbosch University).

Flores, Ritchie and Wolfe (2008) explored the benefits of using a strategic management simulation on the Internet for distance education. In their opinion, the use of simulations brings the business world to the classroom, which provides students with 'hands-on experiences and opportunities to practice strategic decision making' (Flores et al., 2008:101). The end result of the study showed that both simulations via distance education and traditional instruction have advantages and that it is the instructor's responsibility to determine which one is more appropriate under the specific circumstances. Distance education may have the advantage of fostering learning and relieving the instructor of simulation-processing chores. Students under traditional instruction gain a more productive experience, as they have the opportunity to interact with the instructor and the instructor has better knowledge of his or her students. Problems can be anticipated and the instructor can provide much better technical and 
emotional support to the students. Furthermore, students can be coached better and receive real-time feedback from the instructor.

As cited, most available research recommends that management accounting courses should be amended to include practice-oriented exercises and that they should focus on the application of knowledge. Attempts should be made to integrate various skills. It is apparent from these findings that students understand and conceptualise management accounting better if they have already had some exposure to the business environment and terminology before they are exposed to the theory, and that a practical component enhances their academic studies. This supports the idea that professional accounting programmes need to include some type of practical exposure into the academic programme, even if it is only simulated. Furthermore, from above discussion, it appears that a number of benefits may be derived from using management accounting simulations and business plan projects, inter alia, a better understanding of management accounting concepts and real-world management accounting complexities. This research addresses the same topics, but also attempts to test students' perceptions of the benefits derived from the simulation and business plan projects. Similar research on management accounting simulations has not been performed in South Africa.

\section{RESEARCH DESIGN AND METHOD}

\subsection{Overall research design and method}

An extensive literature review was undertaken to identify existing research on the subject of simulations and other teaching tools, such as case studies, in a variety of fields (refer to section 3). These included fields such as business studies, accounting, and non-business fields such as education, and the sciences among others. It may be argued that simulations are a specific form of case study (Wynder, 2004). In addition to the literature discussed in section 3, literature on simulations other than management accounting simulations were also considered in preparing the questionnaire, for example studies by Wynder (2004) on a business simulation and by BakerEveleth, Stone and Pendegraft (2005), who dealt with programming skills. Thereafter a questionnaire was developed to obtain feedback from students on the simulation that was used as part of this research. After the responses were received, the results were analysed to draw conclusions on students' perceptions of the usefulness of the management accounting simulation.

\subsection{Development of the questionnaire and data collection}

Stewart and Dougherty (1993) conducted a study on the use of case studies in teaching accounting. They stated that '[T] he case study approach ... is not intended to replace the textbook, but rather to provide students with a background in the problems of physically requisitioning the data needed' (Stewart \& Dougherty, 1993:2). Horsfield (1995:298) stated that the goal of case studies is to apply theoretical knowledge to 'real-world' scenarios. The management accounting simulation had a similar goal, in that a real-world situation was used to illuminate theory. As literature on simulations is limited, several studies, for example by Stewart and Dougherty (1993), Weil, Oyelere, Yeoh and Firer (2001), Ballantine and Larres (2004) and Hassall and Milne (2004), on the use of case studies and students' perceptions of case studies were consulted in preparing the questionnaire. Studies on non-traditional teaching methods, for example Friedlan (1995), similar to the use of case studies were also consulted. 
To avoid bias in the replies from respondents, an effort was made to distribute potentially related questions throughout the questionnaire. Open-ended questions were also included throughout the questionnaire to support findings from questions relying on a Likert-scale response. The questionnaire was reviewed by two management accounting lecturers, four information systems lecturers and a sample of potential respondents in order to evaluate the validity, unbiased nature and completeness thereof (the questionnaire is available from the authors on request). The questionnaire contained questions covering the following areas:

- demographic and biographical information;

- students' experience of the simulation;

- the perceived benefits and drawbacks of the simulation; and

- the competencies developed while taking part in the simulation.

Traditionally, undergraduate students at South African universities are not exposed to group work. Questions relating to students' perceptions and experience on group work were also included in the questionnaire. These questions formed part of another study, which was outside the scope of this research.

\subsection{Data collection and cleaning}

The questionnaire was made available electronically on WebStudies to the 324 students who had completed the simulation. WebStudies is an e-learning tool that allows surveys to be conducted electronically. All of these students were registered for the information systems course. Completion of the questionnaire was voluntary, and students were given the assurance that their responses would be dealt with anonymously and would have no influence on their marks, in order to avoid bias. From the total population of 324 students, 116 useful responses were obtained, giving a response rate of $35.8 \%$. The electronically completed results were exported to Excel, where they were analysed to draw conclusions. The data was cleaned up by removing instances where students clearly did not attempt to answer the questionnaire or instances of incomplete information. Cluster analysis was performed for analysing the answers to the open-ended questions and the answers were summarised in similar categories.

\subsection{Limitations of the study}

The research encountered a number of limitations:

- the questionnaire tested students' perceptions of the usefulness of the management accounting simulation and not the actual benefit derived;

- information related to gender and previous academic performance in information systems and management accounting was not analysed due to ethical limitations regarding the nature of questions which may be asked from human subjects;

- $\quad$ students have different learning styles (Boyce, Williams, Kelly \& Yee, 2001), which could have had an impact on the results (this fell beyond the scope of this research); and

- various factors, for example student marks, could have an impact on students' perceptions. Furthermore, neither the effect of prior work experience nor prior experience of similar practical teaching methods was tested or analysed. 


\section{BACKGROUND TO THE MANAGEMENT ACCOUNTING SIMULATION}

It is necessary to discuss the various teaching methods utilised to teach management accounting.

\subsection{Traditional management accounting tools}

Traditionally, management accounting lectures consist of a discussion of the theory of a specific topic in lectures, followed by working through an example of the topic, which often requires some form of calculation to be performed. The example is usually worked out by using a calculator and writing down the answer on paper by hand. Students need only to refer to their textbook to assist them in performing the calculation and to explain theory. However, reference to external sources of information to perform the calculation is not necessary, while students are rarely required to perform computer work and modelling. These examples usually are abstract, with little reference to real-life scenarios. This is in contrast with the call for changes in the accounting curriculum, as well as the changes made in the competency frameworks of the professional accounting bodies.

\subsection{Management accounting simulation}

The management accounting simulation differs from traditional management accounting methods in that the simulation creates a real-life scenario to which students are exposed. Furthermore, students need to consult external sources and conduct in-depth research to assist them in compiling the business plan project. This also helps to develop skills, as students are required to think strategically.

This research reports on the students' perceptions of a management accounting simulation that incorporated a business plan project as part of second-year information systems undergraduate course. The participating students were studying towards an accounting degree (Bachelor of Accounting (BAcc)) at Stellenbosch University. All the students were full-time students who had previously completed a one-year information systems course covering Excel techniques. The majority of the students were registered as first-time students with little or no prior work experience. The objective of students registering for the BAcc degree (after completing a postgraduate course) is to pass the Qualifying Examination of the South African Institute of Chartered Accountants (SAICA) conferring the right of the CA(SA) designation upon registration. Management accounting is not the core focus of a BAcc, but forms part of the BAcc programme and is an integral course. The simulation gives students insight into the workings of management accounting and basic strategic thinking in order to draw meaningful conclusions and make appropriate decisions, which is a crucial competency in the business world. It is also stipulated in the SAICA Competency Framework. The information systems course integrates the professional subjects with IT and the simulation contributes to that integration.

This research was based on a project consisting of a management accounting simulation and business plan in which students were required to prepare a strategic business plan for a new business. The strategic business plan had to include the market research, selecting strategies, as well as financial information in the form of budgeted figures for five years. The objective of the simulation was to integrate theoretical management accounting concepts such as strategy selection and budgeting with practical IT skills in order to make management accounting more practical through exposing students to a situation that approximates real life. 
Students were given background information, and the purpose of the management accounting simulation and business plan project were explained. The students were first given information on a hypothetical wine company for which the financial information had to be prepared in Excel.

\subsubsection{Preparing financial information:}

Students were required to prepare a model in Excel to assist them to prepare the budgeted information for the strategic business plan of the company. This information was provided by means of class discussions. Students were taught various formulas and techniques which could be used to complete the individual worksheets that made up the management accounting models they were taught in management accounting classes. These techniques included basic spreadsheet techniques such as data tables and vlookup formulas. The simulation focused on both management accounting and information systems knowledge and required the student to integrate the two fields of study.

Following this, they had to prepare a business plan for a hypothetical company of their choice.

\subsubsection{Preparing business plan}

The business plan covered the following major areas:

- They were required to document their market research on a new business idea/concept which, inter alia, included background information of the business, information on financing options and possible strategies. They also had to select and motivate the entity format.

- The second stage of the business plan required students to prepare budgeted financial information for five years using the model developed in Excel, using management accounting principles.

The project contributed $7 \%$ towards the students' class marks. They also completed two electronic tests, which required the use of the IT techniques and management accounting knowledge to perform business modelling similar to that of the business plan. Each test contributed $8.33 \%$ towards their class mark. Sixty percent of the final examination required students to use knowledge developed during the simulation for answering questions in the examination. It should be borne in mind that the simulation was conducted as part of the information systems course, with the dual objectives of making management accounting more practical and integrating management accounting and IT techniques and skills. Consequently, a considerable amount of time was spent on the IT aspect of the simulation.

\section{EMPIRICAL RESEARCH FINDINGS}

\subsection{Respondent profile}

From the total population of 324 students, 116 useful responses were obtained, giving a response rate of $35.8 \%$, which was regarded as a representative sample in light of the exploratory nature of this study. A majority of $81.9 \%$ of the respondents stated that they had not had any prior exposure to a simulation or a business plan project, and $83.6 \%$ of the respondents stated that they thought that information systems as a subject was an important part of their education and that the management accounting simulation thereby added value to their education. This is interesting, as information systems is a support subject for students and 
not one of the four professional subjects in the programme. Furthermore, students traditionally spend far less time on support subjects than on the professional subjects, because they perceive support subjects as less important.

\subsection{Class attendance}

In light of the fact that it was expected that few students would have been exposed to real-life work experience in preparing a business plan, class attendance was emphasised. The management accounting simulation took the form of a guided simulation for which small sections of the financial information part of the simulation were discussed in lectures and students had to perform the procedures themselves in the following tutorial period, with a theoretical wine company in mind. During each lecture, an in-depth discussion was conducted on the important formulas in Excel that students needed to apply to prepare the financial information. The reasoning behind all the procedures and formulas was discussed and illustrated during lectures. Additional guidance on what to look out for when preparing a business plan was also discussed. Against this background, students were asked to indicate what percentage of time they had spent attending theory and practical classes (TABLE 1 ).

TABLE 1: Class attendance - theory and practical lectures

\begin{tabular}{lcc} 
& Theory lectures & Tutorial classes (practical lectures) \\
\hline Never & $2.6 \%$ & $5.2 \%$ \\
$25 \%$ of classes & $6.0 \%$ & $12.9 \%$ \\
$50 \%$ of classes & $6.0 \%$ & $16.4 \%$ \\
$75 \%$ of classes & $29.3 \%$ & $36.2 \%$ \\
Always & $56.1 \%$ & $29.3 \%$ \\
Total & $100 \%$ & $100 \%$ \\
\hline
\end{tabular}

Source: Research generated

The majority of respondents (91.4\%) estimated that class attendance was in excess of $50 \%$ or more of the theory classes. The tutorial practical classes had a lower class attendance, with only $81.9 \%$ of the respondents attending in excess of $50 \%$ of the classes. The fact that fewer respondents attended the tutorial classes than the theory classes is not an unexpected result, because most of the students would have been able to perform (at least) the basic functions on their own, without the assistance of the lecturer, after having attended the lectures. On the other hand, students in many instances prefer passive learning, with the lecturer doing all the talking and creating the environment for learning, above that of active learning, where students have to ask questions and create their own learning environment. Students furthermore indicated in the questionnaire that the most important constraint they experienced with the business management simulation was insufficient time to complete the simulation. If they had attended the tutorial periods, they would have had one additional hour per week to complete the simulation. The majority $(65.1 \%)$ of the respondents who attended $50 \%$ or more of the lectures felt that the lectures aided them in completing the management accounting simulation. The reason for this is that the context within which IT is used and how it is applicable to management accounting is explained during lectures. The respondents noted that when any 
simulation or task is given to students and "Why it is important?" and the "How it can contribute towards their future?" is properly explained to them by the lecturer, students appear to be motivated to put in more effort towards completing the given task.

\subsection{Preparation from prior learning}

The students were asked whether their management accounting courses had adequately prepared them for the simulation, to which $11.2 \%$ (13) of the respondents answered in the negative. This is a positive outcome, as almost $88 \%$ of students were of the opinion that their management accounting lectures provided adequate preparation for completing the simulation. Although calculations are performed by hand during management accounting lectures, students understand the calculations and are able to re-perform the same calculation in another context, namely Excel. This might be because many of the calculations and formulas taught to students during management accounting lectures are presented in their prescribed textbook in Excel format.

\subsection{Sources of information used to complete the simulation}

In preparing the business plan, students were required to find information from various sources which they had only learnt about in theory. Prior to the simulation, students had always been given the information required in questions, and had not been required to find information from external sources. It is therefore worth considering the sources of information that students used to complete the simulation. Lectures were indicated as one of the sources of information that were used in order to complete the business plan by $63.8 \%$ of the respondents. Again, it was noted that students preferred passive learning to active learning. Consideration should be given to changing the manner in which future simulations are presented to ensure that students depend less on passive learning.

This was a group project and students were encouraged to discuss the simulation among themselves, as well as with other students not necessarily part of the group. Only $12.9 \%$ of the students indicated that they had consulted other students (not in their group). The remainder of the students worked on their own. Working in a team is one of the skills that needs to be introduced into future courses. From this, it can be deduced that, in some instances, students are unwilling to work together in groups. A further indication of this was the many requests received from students for permission to perform the simulation on their own. In a study conducted in 2007 by Steenkamp and Rudman, 76.9\% of the respondents indicated that discussions with other students were used as a source of information. In the current study, $86.2 \%$ of respondents stated that they also used the Internet as a source of information and $30.1 \%$ obtained additional information from library sources. It was interesting to see that students consulted online sources more than notes (commonly referred to as study material by a lecturer) from other subjects. They indicated, in responses to another question, that the management accounting lectures prepared them adequately for the simulation. It is surmised that students preferred online sources because of the large variety of templates of business models; business plans are more freely available, whereas notes and textbooks only explain the concept and principles. A number of students preferred additional discussions or consultations with the lecturer to assist them in completing the simulation. This finding confirms work by Steenkamp and Rudman (2007). TABLE 2 presents the sources of information consulted by students in order of the percentage of respondents making use of the sources indicated. 
TABLE 2: Sources of information

\begin{tabular}{lc}
\hline \multicolumn{1}{c}{$\begin{array}{l}\text { Information source } \\
\text { Internet searches }\end{array}$} & $\begin{array}{c}\text { Percentage oftotal } \\
\text { respondents }\end{array}$ \\
\hline Traditional information systems lectures & $86.2 \%$ \\
\hline Library sources (i.e. books; journals et cetera) & $63.8 \%$ \\
\hline Additional discussions with lecturer outside theory classes & $30.2 \%$ \\
\hline Notes from other subjects & $29.3 \%$ \\
\hline E-books & $26.7 \%$ \\
\hline Discussions with and notes from other students & $17.2 \%$ \\
\hline Management accounting notes & $12.9 \%$ \\
\hline
\end{tabular}

Source: Research generated

(Respondents were able to select more than one of the options; therefore the total exceeds 100\%.)

From TABLE 2 above it appears that students mainly consulted three sources of information: online sources, followed by discussions with lecturers and books (other than their textbooks). Least reliance was placed on notes.

\subsection{Usefulness of the management accounting simulation and business plan project for teaching various competencies}

In order to answer the first research question, the questionnaire contained 31 questions testing students' opinions on the usefulness of the management accounting simulation for teaching various competencies. Students were able to answer on a four-point Likert scale varying from 'Not at all [useful]' to 'Extensively [useful]'. The responses to all 31 questions are summarised in Appendix A. The results from the 31 questions indicated that the main objectives of the simulation, namely to integrate management accounting with IT and to make management accounting more practical, had been achieved. The five most important competencies learned by students form the simulation, in order of usefulness (with the percentage of respondents who perceived the particular item to be either considerably or extensively useful in brackets), are ranked as follows:

- understanding of how information systems fits into the accounting curriculum, thus underpinning the importance of information systems in a student's future career (71.6\%);

- the ability to integrate the understanding of the different components of the information systems course and consolidate students' prior knowledge of the discipline (67.2\%);

- analytical skills (defined as the ability to think in a logical and systematic manner) (66.4\%);

- skill in interpreting large volumes of data (defined as the ability to understand and decipher data) $(65.5 \%)$; and

- the ability to think critically about issues (65.5\%). 
The first two competencies assisted in achieving the objective of the simulation. Two key issues were highlighted by the students as important skills which the simulation helped to develop: (i) it placed information systems in context and helped to provide a context for information systems for students and (ii) it allowed students to gather information from various sources (refer to section 6.4) and analyse the information to consider how this information fitted into a specific business context. Students had to gather information and decide which was relevant to their business concept. This also meant that the students continued to learn from other sources that they might not have consulted or learnt from otherwise.

The factors that contribute to the development of various competencies listed below were not successfully enhanced by the management accounting simulation, with $75 \%$ or more of the respondents feeling that the management accounting simulation was 'not at all useful' or, at best, 'a little bit useful' (classified in total as 'not optimally useful' in Appendix A). The percentage between brackets indicates the percentage of respondents who held the opinion that it was 'not optimally useful'.

- students' motivation to study information systems (34.5\%);

- students' interest in the subject and stimulating discussions around the problem (23.3\%);

- students' active listening skills (22.4\%);

- the ability to think conceptually (in other words, the ability to 'think outside the box') $(19.9 \%)$; and

- the ability to prioritise when dealing with multi-problem situations and, in doing so, identifying the problems which required immediate action (19.0\%).

The management accounting simulation will be amended to attempt to address these shortcomings in future, by requiring students to prepare a presentation on the business plan for assessment. This would require students to interact more with other students. Similarly, constraints could be introduced into the simulation; students' options when formulating the business plan might be limited by, for example, imposing capital constraints, or limiting the market frontiers, thereby requiring students to think outside the box and prioritise options.

\subsection{Perceived potential benefits of the management accounting simulation and business plan project for students}

The questionnaire contained a variety of questions to gauge the students' perceptions of various potential benefits of the management accounting simulation in order to answer the second research question. $50 \%$ of the respondents indicated that the management accounting simulation contributed to their learning and understanding of the management accounting courses. This is important, because the skills highlighted in the previous section helped to develop the skills necessary for students to answer the new types of management accounting questions that, for example, focus on strategy and discussion questions, rather than numbersdriven questions. Although all students do not believe that the simulation helped them to answer exam papers better, the skills that were highlighted are the skills that were needed to answer the management accounting papers. The students just did not realise this. Students were asked whether the simulation had contributed to their studies in various ways. The results are presented in TABLE 3 . 
TABLE 3: Contribution of the simulation to different areas of students' studies

\begin{tabular}{lc}
\hline \multicolumn{1}{c}{ The management accounting simulation will enhance students' ability to: } & Percentage \\
\hline ... answer information systems papers & $72.4 \%$ \\
... better conceptualise management accounting & $54.0 \%$ \\
... answer management accounting papers & $36.2 \%$ \\
\hline
\end{tabular}

Source: Research generated

Given the nature of assessment and the objective of the course to teach the students Excel techniques, it is understandable that $72.4 \%$ of respondents stated that the simulation assisted them to answer information systems questions. More than half of the respondents experienced the simulation positively and believed that it contributed to their studies as a whole.

The evidence suggested that the management accounting simulation contributed and/or enhanced the students' interest in their studies to an extent in general (56.9\% of respondents); and $62.9 \%$ of the respondents believed that they had experienced an increase in interest in information systems and $37.1 \%$ believed this in terms of management accounting. Overall, students felt that the simulation was a valuable tool in their studies, with $88.8 \%$ agreeing that they had learnt and remembered more from the simulation than they would have from any other teaching method that they had experienced before. This is because simulation helps with conceptualisation of the subject (54\%). Only $6.9 \%$ of the respondents felt that the time spent on the simulation could have been better spent studying on their own. It could be surmised that students value learning through memorisation more than understanding. This is attributable to the assessment models used.

Students were given the opportunity to list the three most important benefits arising from using the management accounting simulation as a teaching and learning tool. They were asked an open-ended question and the results are summarised in similar groupings in TABLE 4. It is interesting to note that four of the competencies (time management skills, research skills, problem-solving skills and oral communication skills) identified by the respondents are in fact the pervasive competencies that students should acquire in terms of the SAICA competency framework.

TABLE 4: Most important benefits of management accounting simulation

\begin{tabular}{lc}
\hline & $\begin{array}{c}\text { Percentage of total } \\
\text { respondents }\end{array}$ \\
\hline Learning the skills to operate in a team situation & $31.0 \%$ \\
\hline $\begin{array}{l}\text { Applying theory in practical scenario and making management accounting } \\
\text { more practical (real-life experience) }\end{array}$ & $29.3 \%$ \\
Time-management skills & $12.9 \%$ \\
Research skills & $11.2 \%$ \\
Problem-solving skills & $6.9 \%$ \\
Oral communication skills & $6.0 \%$
\end{tabular}




\begin{tabular}{lc} 
Enhancing computer skills & $6.0 \%$ \\
\hline Integrating different subjects & $5.2 \%$ \\
\hline Broader knowledge of subjects & $4.3 \%$ \\
\hline Conceptual thinking skills & $3.4 \%$ \\
\hline Other & $23.3 \%$ \\
\hline
\end{tabular}

Source: Research generated

(Respondents were able to select more than one of the options; therefore the total exceeds $100 \%$.)

The benefits that the respondents listed focus on four main areas: teamwork (this is positive as this is one of the first opportunities students had to perform a task as a team); application of knowledge; pervasive skills and thinking skills (problem-solving and conceptual thinking). The first two benefits were the stated objectives of the simulation, and the respondents were of the opinion that these objectives had been achieved. It is noteworthy that this was derived from an open-ended question and that, as a result, the students gave their own opinions without bias. This therefore validates the use of the management accounting simulation as a teaching tool. The benefits listed as "other" specified by $23.3 \%$ of the respondents (refer to TABLE 4) consisted of a wide variety of items, for example, coaching team members, motivating team members to perform, delegation skills, planning skills and how to think creatively. These are mainly related to pervasive skills.

To support the 31 competencies referred to in section 6.5, respondents were asked to rank the five most important competencies which they believed they had mastered during the simulation in order of importance. The five most important competencies listed by the students are as follows (with the percentage of respondents who perceived the particular item to be either considerably or extensively useful in brackets):

- understanding of how information systems fits into the accounting curriculum, thus underpinning the importance of information systems is one's future career (31.9\%);

- the willingness to take responsibility for one's own learning (28.4\%);

- insight into practical operations of a business (25\%);

- the ability to think conceptually (in other words, the ability to 'think outside the box') $(24.1 \%)$; and

- students' problem-solving skills (23.3\%).

Interestingly, three of the five competencies that students ranked as competencies they were taught during the simulation (refer to section 6.5) agree with the result of the individual competencies students had to select from the separate 31 competencies. It was encouraging to note that among the main skills that students believed they had gained was understanding where information systems fits into their future career, as well as how management accounting works in practice. 


\subsection{Constraints arising from the management accounting simulation and business plan project}

Students were asked to list the three most significant constraints or disadvantages arising from the simulation (refer to research question 3). These are summarised in TABLE 5.

TABLE 5: Main perceived constraints of the management accounting simulation and business plan

\begin{tabular}{lc}
\hline & $\begin{array}{c}\text { Percentage of total } \\
\text { respondents }\end{array}$ \\
\hline Time constraints & $36.2 \%$ \\
Not all members put in same effort & $6.9 \%$ \\
Requirements provided unclear & $6.0 \%$ \\
Lack of interest/enthusiasm/motivation & $5.2 \%$ \\
Finding relevant sources & $4.3 \%$ \\
Oral and communication issues & $3.4 \%$ \\
Other & $44.8 \%$ \\
\hline
\end{tabular}

Source: Research generated

(Respondents were able to select more than one of the options; therefore the total exceeds 100\%.)

Unlike the benefits which the respondents perceived to focus on a couple of main benefits, the respondents listed a wide variety of drawbacks. The main drawback was time constraints: $36.2 \%$ of respondents felt that the simulation took too much time. The time constraints included finding time to complete the simulation and finding a time to meet that suited all team members. In addition, many students were of the opinion that the time spent on the simulation should rather have been used to study. This highlights the need for students to learn to multitask, plan and manage time. Another concern is that students felt that the requirements that were provided were unclear. This may be ascribed to the fact that $20.7 \%$ of the students indicated that they had not read the instructions of the project before commencing the simulation. Another aspect that stands out is the social aspect, with students struggling with communication within the group, with getting other students to remain motivated (in addition to increasing their own motivation) and with bringing different ideas from other students together to develop a comprehensive idea.

\subsection{Appropriateness of management accounting simulation and business plan project as teaching method}

Overall, $88.7 \%$ of respondents indicated that the management accounting simulation was an appropriate method of teaching management accounting. This does not argue in favour of eliminating management accounting lectures, as the theory underlying the practice must still be taught (Siegel et al., 1997). However, it does indicate that the respondents appreciated the more practical approach, which allowed them to conceptualise the subject in a practical 
scenario. This creates the opportunity for management accounting lecturers to find ways to make the subject more practical by, for example, including small projects in the course and encouraging students to apply for vacation work at companies during university holidays.

of the respondents, $77.6 \%$ indicated that the simulation should be extended to cover other core financial accounting, auditing and taxation areas, and should be a means of teaching the practical application of the subjects. This confirms findings by Steenkamp and Rudman (2007) and Rudman and Terblanche (2011) that modern students require a more practical approach. It also presents lecturers with the dilemma of the accounting education syllabus becoming overburdened with detailed content. This raises the questions for future research: How does one balance this detailed and specialist knowledge with the practical approach required by modern generation y students? How can academia deliver students with specialist knowledge while also delivering students with the pervasive skills required by companies?

\section{SUMMARY AND CONCLUSION}

This research reports on the results of a survey conducted to test the perceptions of students regarding the usefulness of a management accounting simulation that incorporated a business plan project. The findings of the research, as discussed in section 6, confirm findings derived in other fields. Key findings from Sawyer, Tomlinson and Maples (2000) were that competencies such as decision-making and problem-solving can be developed in students only if an interactive environment between the student and real life is created within the classroom so that the student can experience a real-life situation. In this research, students indicated that problem-solving was one of the competencies they acquired through the simulation. They also indicated that they valued the exposure to a practical approach, which was a key finding in the research study conducted by Stainbank (2003). It also adds various new insights into students' perceptions and experiences in a South African context. The management accounting simulation made a valuable contribution to students' studies, assisting them in conceptualising management accounting and making theory more practical. These findings therefore address the main objectives of the management accounting simulation. The respondents agreed that the simulation was a more appropriate way to teach management accounting and felt that it should be extended to other subjects.

This study confirms Steenkamp and Rudman's (2007) findings that students found the simulation to be time-consuming. The time required to complete the simulation and business plan was noted as an important constraint. It is easier or more convenient for students to memorise details than to analyse a problem, conduct research and prepare a solution for the problem. Students are used to spending less time on their subjects (when they only have to study for tests and examinations), compared to conducting a detailed simulation. However, it is surmised that the more students engage in simulations, the easier and less time-consuming it will become in the long run as students become more accustomed to simulations. This is worth considering in the development of similar study aids. The study showed that students are not comfortable with working in groups. A study to determine what students' perceptions are with regard to engaging in simulations and projects in groups was identified as an area for future research. This study is currently in progress.

In conclusion, the goals of the project to integrate management accounting and IT and make management accounting more practical were met. The respondents indicated that they thought the management accounting simulation incorporating a business plan project was a useful part 
of their studies and that consideration should therefore be given to including it as a part of students' courses. It is believed that this research has added to current understanding of issues faced by students participating in a management accounting simulation and that it should be of value in developing and implementing similar study aids.

\section{LIST OF REFERENCES}

Accounting Education Change Commission (1990). Position Statement Number one: Objectives of Education for Accountants. [Online] Available: http://aaahq.org/AECC/pdf/position/posl.pdf. (Accessed 11 April 2012).

American Accounting Association (1989). The Big Eight White Paper-Perspectives on Education: Capabilities for Success in the Accounting Profession. [Online] Available: http://aaahq.org/aecc/. (Accessed 23 May 2012).

Ahadiat, N. (2008). In search of practice-based topics for management accounting education. Management Accounting Quarterly, 9(4), pp. 42-54.

Adler, R.W. \& Milne, M.J. (1997). Improving the quality of accounting students' learning through action-oriented learning tasks. Accounting Education, 6(3), pp. 191-215.

Albrecht, W.S. \& Sack, R.J. (2000). Accounting education: charting the course through a perilous future. Accounting Education Series No. 16. Sarasot, Florida: American Accounting Association, pp. $1-72$.

Baker-Eveleth, L., Stone, R.W. \& Pendegraft, N. (2005). Changes in students' perceptions of programming skills using class projects. Journa/ of Business and Management, 11, pp. 25-40.

Ballantine, J.A. \& Larres, P.M. (2004). A critical analysis of students' perceptions of the usefulness of the case study method in an advanced management accounting module: the impact of relevant work experience. Accounting Education, 13(2), pp. 171-189.

Borthick, A.F. \& Curtis, M.B. (2004). Audit simulation for due diligence on fast-fashion inventory through data querying. [Online] Available:

http://www2.gsu.edu/ accafb/pubs/BorthickCurtisThreadSim2004.pdf. (Accessed 11 April 2012).

Botha, W.J.J. (2001). Pre-qualification education of registered accountants and auditors in South Africa: perspectives on whether the education process is normatively justifiable. Meditari Accountancy Research, 9, pp. 33-59.

Boyce, G., Williams, S., Kelly, A. \& Yee, H. (2001). Fostering deep and elaborative learning and generic (soft) skill development: the strategic use of case studies in accounting education. Accounting Education, 10(1), pp. 37-60.

Chartered Institute of Management Accountants (CIMA), (2010). Qualification structure and syllabus. CIMA Chartered Management Accounting Qualification 2010.

Dennis, I. (2003). OK in practice - and theory. Accounting Education, 12(4), pp. 415-426.

De Wet, J.H. \& Van Niekerk, M.C. (2001). An innovative approach to accounting education at the firstyear level. Meditari Accountancy Research, 9, pp. 93-108.

Flores, L.G., Ritchie, W.J. \& Wolfe, J. (2008). Exploring distance education as an alternative to locally administered business strategy simulations: The case of two Universities. Review of Business Research, 8(3), pp. 101-109. 
Friedlan, J.M. (1995). The effects of different teaching approaches in students' perceptions of the skills needed for success in accounting courses and by practicing accountants. Issues in Accounting Education, 10(1), pp. 47-63.

Gentry, J.W. (1990). Guide to business gaming and experiential learning. London: Kogan. [Online] Available: http://sbaweb.wayne.edu/ absel/bkl/BGcov.pdf. (Accessed 30 August 2012).

Hassall, T., Lewis, S. \& Broadbent, M. (1998). Teaching and learning using case studies: a teaching note. Accounting Education, 7(4), pp. 325-334.

Hassall, T. \& Milne, M.J. (2004). Using case studies in accounting education. Accounting Education, 13(2), pp. 135-138.

Horsfield, L. (1995). Factors to consider when choosing a computerized case study for an undergraduate auditing course. Accounting Education, 4(4), pp. 297-318.

Johnson, E.N., Baird, J., Caster, P., Dilla, W.N., Early, C.E. \& Louwers, T.J. (2003). Challenges to audit education for the 21 st century: a survey of curricula, course content, and delivery methods: the 2000-2001 Auditing Section Committee American Accounting Association. Issues in Accounting Education. August, 18(3), pp. 241-263.

Lightbody, M. (1997). Teaching note - Playing factory: active-based learning in cost and management accounting. Accounting Education, 6(3), pp. 255-262.

Massey, D.W., Poli, P.M. \& Proctor, R.J. 2002. The development and evaluation of a team-based audit simulation in the introductory auditing course. [Online] Available:

http://aaahq.org/northeast/Abstracts/Massey.pdf. (Accessed 11 April 2012)

May, R.G. 1992. Phase I: CableCo Chronicles. In Smith J.M. (Ed) (1992). Curriculum Innovation:

Excellence in Audit Education, 23-35. The Auditing section of the American Accounting Association and the Coopers \& Lybrand Foundation.

Palmer, K.N., Ziegenfuss, D.E. \& Pinsker, R.E. (2004). International knowledge, skills, and abilities of auditors/accountants: evidence from recent competency studies. Managerial Auditing Journal, 19(7), pp. 889-896.

Rudman, R.J. \& Terblanche, J. (2011). Practical role-play as an extension to theoretical audit education: a conceptualising aid. Southern African Journal of Accountability and Auditing Research, 11, pp. 63-74.

Sawyer, A.J., Tomlinson, S.R. \& Maples. A.J. (2000). Developing essential skills through case study scenarios. Journal of Accounting Education, 18(3), pp. 257-262.

Sadler, ع. \& Erasmus, B.J. (2005). The academic success and failure of black chartered accounting graduates in South Africa: a distance education perspective. Meditari Accountancy Research, 13(1), pp. 29-50.

Siegel, P.H., Omer, K. \& Agrawal, S.P. (1997). Video simulation of an audit: an experiment in experiential learning theory. Accounting Education, 6(3), pp. 217-230.

South African Institute for Chartered Accountants (SAICA) (2010). Competency Framework. Detailed guidance for Academic Programmes. [Online] Available:

https://www.saica.co.za/Portals/0/LearnersStudents/documents/INTEGRITAS-292277.pdf. (Accessed 22 May 2012)

Springer, C.W. \& Borthick, A.F. (2004). Business simulation to stage critical thinking in introductory accounting: rationale, design, and implementation. Issues in Accounting Education, 19(3), pp. $277-$ 303. 
Stainbank, L.J. (2003). Using an annual report as a group project in accounting education. Meditari Accountancy Research, 11, pp. 161-166.

Stainbank, L.J. (2005). Students' perceptions of the usefulness of an annual report project for the development of skills and knowledge. Meditari Accountancy Research, 13(2), pp. 129-144.

Steenkamp, L.P. \& Rudman, R.J. (2007). South African students' perceptions of the usefulness of an audit simulation. Meditari Accountancy Research, 15(2), pp. 23-41.

Stewart, J.P. \& Dougherty, T.W. (1993). Using case studies in teaching accounting: a quasiexperimental study. Accounting Education, 2(1), pp. 1-10.

Visser, S., McChlery, S. \& Vreken, N. (2006). Teaching styles versus learning styles in the accounting sciences in the United Kingdom and South Africa: a comparative analysis. Meditari Accountancy Research, 15(2), pp. 97-112.

Weil, S., Oyelere, P., Yeoh, J. \& Firer, C. (2001). A study of students' perceptions of the usefulness of case studies for the development of finance and accounting-related skills and knowledge. Accounting Education, 10(2), pp. 123-146.

Wessels, P.L. (2005). Critical information and communication technology (ICT) skills for professional accountants. Meditari Accountancy Research, 13(1), pp. 87-103.

Wessels, P.L. \& Steenkamp, L.P. (2007). The ability of students to convert their knowledge of IT concepts into IT competencies. Meditari Accountancy Research, 15(2), pp. 113-129.

Wessels, P.L \& Steenkamp, L.P. (2009). An investigation into students' perceptions of accountants. Meditari Accountancy Research, 17(1), pp. 117-132.

Wolmarans, H.P. (2005). Business simulations in financial management courses: Are they valuable to learners? Meditari Accountancy Research, 13(1), pp. 121-133.

Wynder, M. (2004). Facilitating creativity in management accounting: a computerized business simulation. Accounting Education, 13(2), pp. 231-250. 


\section{APPENDIX A}

In addition to the other questions, students were provided with 31 questions testing their opinion on the usefulness of the simulation and project in teaching various competencies, compared to lectures and traditional learning methods. They were able to answer on a fourpoint Likert scale varying from 'Not at all [useful]' to 'Extensively [useful]'. 'Not at alf and a 'a little bit' were grouped as 'not optimally usefup', while 'to an extent' and 'extensively were grouped as 'usefup. The results as appeared in the questionnaire are summarised as:

\begin{tabular}{|c|c|c|c|c|c|c|c|}
\hline & $\begin{array}{c}\text { To what extent did the } \\
\text { project help you to } \\
\text { develop, improve, enhance } \\
\text { or enable: }\end{array}$ & $\begin{array}{c}\text { Not at } \\
\text { all }\end{array}$ & $\begin{array}{c}\text { A little } \\
\text { bit }\end{array}$ & $\begin{array}{c}\text { Not } \\
\text { optimally } \\
\text { useful* }\end{array}$ & $\begin{array}{l}\text { To an } \\
\text { extent }\end{array}$ & $\begin{array}{l}\text { Exten- } \\
\text { sively }\end{array}$ & Useful* \\
\hline 1 & $\begin{array}{l}\text { your judgement skills } \\
\text { (defined as identifying and } \\
\text { choosing between available } \\
\text { alternatives)? }\end{array}$ & $3.4 \%$ & $13.8 \%$ & $17.2 \%$ & $42.2 \%$ & $6.9 \%$ & $49.1 \%$ \\
\hline 2 & $\begin{array}{l}\text { your ability to distinguish } \\
\text { between cause and effect in } \\
\text { an unstructured business (or } \\
\text { management accounting) } \\
\text { situation, thereby requiring } \\
\text { you to make relevant } \\
\text { assumptions and identify } \\
\text { limitations? }\end{array}$ & $3.4 \%$ & $13.8 \%$ & $17.2 \%$ & $44.8 \%$ & $5.2 \%$ & $50 \%$ \\
\hline 3 & $\begin{array}{l}\text { the ability to integrate your } \\
\text { understanding of the } \\
\text { different components of the } \\
\text { information systems course } \\
\text { and consolidate your prior } \\
\text { knowledge of the discipline? }\end{array}$ & $0.9 \%$ & $12.1 \%$ & $13 \%$ & $53.4 \%$ & $13.8 \%$ & $67.2 \%$ \\
\hline 4 & $\begin{array}{l}\text { the ability to integrate your } \\
\text { understanding of the } \\
\text { different components of } \\
\text { other courses? }\end{array}$ & $4.3 \%$ & $13.8 \%$ & $18.1 \%$ & $40.5 \%$ & $12.9 \%$ & $53.4 \%$ \\
\hline 5 & $\begin{array}{l}\text { the skills in interpreting } \\
\text { large volumes of data } \\
\text { (defined as the ability to } \\
\text { understand and decipher } \\
\text { data)? }\end{array}$ & $1.7 \%$ & $8.6 \%$ & $10.3 \%$ & $50 \%$ & $15.5 \%$ & $65.5 \%$ \\
\hline 6 & $\begin{array}{l}\text { your ability to think } \\
\text { critically about issues? }\end{array}$ & $1.7 \%$ & $12.1 \%$ & $13.8 \%$ & $49.1 \%$ & $16.4 \%$ & $65.5 \%$ \\
\hline 7 & $\begin{array}{l}\text { your analytical skills } \\
\text { (defined as the ability to } \\
\text { think in a logical and in a } \\
\text { systematic manner)? }\end{array}$ & $1.7 \%$ & $10.3 \%$ & $12 \%$ & $48.3 \%$ & $18.1 \%$ & $66.4 \%$ \\
\hline 8 & the ability to consider & $0.0 \%$ & $12.1 \%$ & $12.1 \%$ & $38.8 \%$ & $19.0 \%$ & $57.8 \%$ \\
\hline
\end{tabular}




\begin{tabular}{|c|c|c|c|c|c|c|c|}
\hline & $\begin{array}{c}\text { To what extent did the } \\
\text { project help you to } \\
\text { develop, improve, enhance } \\
\text { or enable: }\end{array}$ & $\begin{array}{c}\text { Not at } \\
\text { all }\end{array}$ & $\begin{array}{l}\text { A little } \\
\text { bit }\end{array}$ & $\begin{array}{l}\text { Not } \\
\text { optimally } \\
\text { useful* }\end{array}$ & $\begin{array}{l}\text { To an } \\
\text { extent }\end{array}$ & $\begin{array}{l}\text { Exten- } \\
\text { sively }\end{array}$ & Useful* \\
\hline & $\begin{array}{l}\text { problems and evaluate a } \\
\text { situation from more than } \\
\text { one perspective? }\end{array}$ & & & & & & \\
\hline 9 & $\begin{array}{l}\text { your ability to synthesise } \\
\text { (combine) the essential } \\
\text { elements of a given } \\
\text { situation? }\end{array}$ & $0.9 \%$ & $11.2 \%$ & $12.1 \%$ & $44.8 \%$ & $13.8 \%$ & $58.6 \%$ \\
\hline 10 & your active listening skills? & $12.1 \%$ & $10.3 \%$ & $22.4 \%$ & $25 \%$ & $10.3 \%$ & $35.3 \%$ \\
\hline 11 & your problem-solving skills? & $1.7 \%$ & $14.7 \%$ & $16.4 \%$ & $49.1 \%$ & $12.1 \%$ & $61.2 \%$ \\
\hline 12 & $\begin{array}{l}\text { you to take decisions with } \\
\text { incomplete information? }\end{array}$ & $3.4 \%$ & $12.9 \%$ & $16.3 \%$ & $42.2 \%$ & $17.2 \%$ & $59.4 \%$ \\
\hline 13 & $\begin{array}{l}\text { your skill in evaluating } \\
\text { ideas? }\end{array}$ & $0.0 \%$ & $7.6 \%$ & $7.6 \%$ & $47.4 \%$ & $15.5 \%$ & $62.9 \%$ \\
\hline 14 & $\begin{array}{l}\text { your ability to consider } \\
\text { alternative solutions and } \\
\text { applying judgement on the } \\
\text { most appropriate course of } \\
\text { action? }\end{array}$ & $0.9 \%$ & $5.2 \%$ & $6.1 \%$ & $48.3 \%$ & $16.4 \%$ & $64.7 \%$ \\
\hline 15 & $\begin{array}{l}\text { your motivation of study } \\
\text { information systems? }\end{array}$ & $19.0 \%$ & $15.5 \%$ & $34.5 \%$ & $25.0 \%$ & $7.8 \%$ & $32.8 \%$ \\
\hline 16 & $\begin{array}{l}\text { your understanding of how } \\
\text { information systems fits into } \\
\text { the accounting curriculum, } \\
\text { thus underpinning the } \\
\text { importance of information } \\
\text { systems in your future } \\
\text { career? }\end{array}$ & $0.0 \%$ & $9.5 \%$ & $9.5 \%$ & $46.6 \%$ & $25.0 \%$ & $71.6 \%$ \\
\hline 17 & $\begin{array}{l}\text { your ability to ask pertinent } \\
\text { questions? In other words } \\
\text { breaking the problem down } \\
\text { into its underlying parts. }\end{array}$ & $2.6 \%$ & $7.8 \%$ & $10.4 \%$ & $43.1 \%$ & $12.1 \%$ & $55.2 \%$ \\
\hline 18 & $\begin{array}{l}\text { you to prioritise when } \\
\text { dealing with multi-problem } \\
\text { situations and in doing so } \\
\text { identifying problems which } \\
\text { required immediate action? }\end{array}$ & $2.6 \%$ & $16.4 \%$ & $19.0 \%$ & $39.7 \%$ & $12.9 \%$ & $52.6 \%$ \\
\hline 19 & $\begin{array}{l}\text { your active participation in } \\
\text { the learning process? }\end{array}$ & $3.4 \%$ & $14.7 \%$ & $18.1 \%$ & $41.4 \%$ & $15.5 \%$ & $56.9 \%$ \\
\hline 20 & $\begin{array}{l}\text { you to express ideas and } \\
\text { opinions, formulate } \\
\text { arguments or } \\
\text { recommendations and }\end{array}$ & $1.7 \%$ & $12.9 \%$ & $14.6 \%$ & $43.1 \%$ & $18.1 \%$ & $61.2 \%$ \\
\hline
\end{tabular}




\begin{tabular}{|c|c|c|c|c|c|c|c|}
\hline & $\begin{array}{c}\text { To what extent did the } \\
\text { project help you to } \\
\text { develop, improve, enhance } \\
\text { or enable: }\end{array}$ & $\begin{array}{c}\text { Not at } \\
\text { all }\end{array}$ & $\begin{array}{c}\text { A little } \\
\text { bit }\end{array}$ & $\begin{array}{l}\text { Not } \\
\text { optimally } \\
\text { useful* }\end{array}$ & $\begin{array}{l}\text { To an } \\
\text { extent }\end{array}$ & $\begin{array}{l}\text { Exten- } \\
\text { sively }\end{array}$ & Useful* \\
\hline & $\begin{array}{l}\text { articulate ideas in written } \\
\text { form? }\end{array}$ & & & & & & \\
\hline 21 & $\begin{array}{l}\text { your oral communication } \\
\text { skills (to express ideas and } \\
\text { opinions, formulate } \\
\text { arguments or } \\
\text { recommendations and } \\
\text { articulate ideas for the } \\
\text { purpose of influencing the } \\
\text { thinking of others)? }\end{array}$ & $9.5 \%$ & $8.6 \%$ & $18.1 \%$ & $37.1 \%$ & $10.3 \%$ & $47.4 \%$ \\
\hline 22 & $\begin{array}{l}\text { you to relate theory and } \\
\text { technical knowledge in } \\
\text { accounting, management } \\
\text { accounting, auditing et } \\
\text { cetera to real-life situations } \\
\text { or practical problems (with } \\
\text { complexities and ambiguous } \\
\text { information)? }\end{array}$ & $0.0 \%$ & $12.9 \%$ & $12.9 \%$ & $44.0 \%$ & $12.9 \%$ & $56.9 \%$ \\
\hline 23 & $\begin{array}{l}\text { Encourage you to apply your } \\
\text { technical knowledge to new } \\
\text { and unique situations? }\end{array}$ & $0.0 \%$ & $11.2 \%$ & $11.2 \%$ & $46.6 \%$ & $15.5 \%$ & $62.1 \%$ \\
\hline 24 & $\begin{array}{l}\text { your insight into the } \\
\text { practical operations of a } \\
\text { business? }\end{array}$ & $0.0 \%$ & $7.8 \%$ & $7.8 \%$ & $40.5 \%$ & $22.4 \%$ & $62.9 \%$ \\
\hline 25 & $\begin{array}{l}\text { your ability to identify } \\
\text { information relevant to the } \\
\text { particular task you are } \\
\text { completing? (thereby to } \\
\text { distinguish macro issues } \\
\text { from the micro issues, thus } \\
\text { focusing on the most } \\
\text { important and relevant } \\
\text { facts) }\end{array}$ & $0.9 \%$ & $15.5 \%$ & $16.4 \%$ & $37.9 \%$ & $14.7 \%$ & $52.6 \%$ \\
\hline 26 & $\begin{array}{l}\text { your ability to summarise } \\
\text { information? }\end{array}$ & $0.9 \%$ & $12.1 \%$ & $13.0 \%$ & $39.7 \%$ & $12.1 \%$ & $51.8 \%$ \\
\hline 27 & $\begin{array}{l}\text { develop your problem } \\
\text { identification skills? }\end{array}$ & $0.9 \%$ & $14.7 \%$ & $15.6 \%$ & $47.4 \%$ & $11.2 \%$ & $58.6 \%$ \\
\hline 28 & $\begin{array}{l}\text { your ability to think } \\
\text { conceptually? In other } \\
\text { words, your ability to "think } \\
\text { outside the box". }\end{array}$ & $7.8 \%$ & $12.1 \%$ & $19.9 \%$ & $37.9 \%$ & $17.2 \%$ & $55.1 \%$ \\
\hline 29 & $\begin{array}{l}\text { you to distinguish facts from } \\
\text { opinions? }\end{array}$ & $2.6 \%$ & $13.8 \%$ & $16.4 \%$ & $34.5 \%$ & $8.6 \%$ & $43.1 \%$ \\
\hline
\end{tabular}


Rudman \& Kruger

\begin{tabular}{|c|c|c|c|c|c|c|c|}
\hline & $\begin{array}{c}\text { To what extent did the } \\
\text { project help you to } \\
\text { develop, improve, enhance } \\
\text { or enable: }\end{array}$ & $\begin{array}{c}\text { Not at } \\
\text { all }\end{array}$ & $\begin{array}{c}\text { A little } \\
\text { bit }\end{array}$ & $\begin{array}{l}\text { Not } \\
\text { optimally } \\
\text { useful* }\end{array}$ & $\begin{array}{c}\text { To an } \\
\text { extent }\end{array}$ & $\begin{array}{l}\text { Exten- } \\
\text { sively }\end{array}$ & Useful* \\
\hline 30 & $\begin{array}{l}\text { a willingness to take } \\
\text { responsibility for your own } \\
\text { learning? }\end{array}$ & $1.7 \%$ & $12.1 \%$ & $13.8 \%$ & $31.9 \%$ & $22.4 \%$ & $54.3 \%$ \\
\hline 31 & $\begin{array}{l}\text { your interest in the subject } \\
\text { and stimulate discussions } \\
\text { around the problem? }\end{array}$ & $8.6 \%$ & $14.7 \%$ & $23.3 \%$ & $37.9 \%$ & $9.5 \%$ & $47.4 \%$ \\
\hline
\end{tabular}

\section{Source: Research generated}

* The totals for these columns do not add up to $100 \%$, because room was made for an option for students to select "indifferent" to the particular skill. In order to increase readability, a separate column was not included for this factor. 